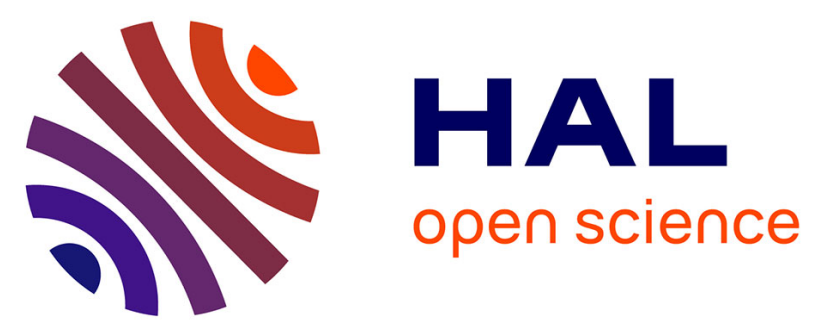

\title{
An attitude model of environmental action : evidence from developing and developed countries
}

Cristina Davino, Vincenzo V. Esposito Vinzi, Estefania Santacreu-Vasut, Radu Vranceanu

\section{To cite this version:}

Cristina Davino, Vincenzo V. Esposito Vinzi, Estefania Santacreu-Vasut, Radu Vranceanu. An attitude model of environmental action: evidence from developing and developed countries. 2017. hal-01457539

\section{HAL Id: hal-01457539 \\ https://essec.hal.science/hal-01457539}

Preprint submitted on 6 Feb 2017

HAL is a multi-disciplinary open access archive for the deposit and dissemination of scientific research documents, whether they are published or not. The documents may come from teaching and research institutions in France or abroad, or from public or private research centers.
L'archive ouverte pluridisciplinaire HAL, est destinée au dépôt et à la diffusion de documents scientifiques de niveau recherche, publiés ou non, émanant des établissements d'enseignement et de recherche français ou étrangers, des laboratoires publics ou privés. 


\title{
E \\ ESS EC \\ BUSINESS SCHOOL
}

\section{AN ATTITUDE MODEL OF ENVIRONMENTAL ACTION: EVIDENCE FROM DEVELOPING AND DEVELOPED COUNTRIES}

\author{
RESEARCH CENTER \\ CRISTINA DAVINO, VINCENZO ESPOSITO VINZI, \\ ESTEFANIA SANTACREU-VASUT, RADU VRANCEANU \\ ESSEC WORKING PAPER 1703
}

JANUARY 2017 


\title{
An attitude model of environmental action: evidence from developing and developed countries
}

\author{
Cristina DAVINO \\ University of Macerata, Piazza Strambi 1, 62100 Macerata MC, Italy. \\ E-mail: cristina.davino@unimc.it.
}

\section{Vincenzo ESPOSITO VINZI}

ESSEC Business School and THEMA, 3 Av. Bernard Hirsch, 95021 Cergy, France.

E-mail: vinzi@essec.edu.

\author{
Estefania SANTACREU-VASUT \\ Corresponding author. ESSEC Business School and THEMA, 3 Av. Bernard Hirsch, 95021 Cergy, France. \\ E-mail: santacreuvasut@essec.edu.
}

\section{Radu VRANCEANU}

ESSEC Business School and THEMA, 3 Av. Bernard Hirsch, 95021 Cergy, France.

E-mail: vranceanu@essec.edu. 


\begin{abstract}
This paper analyzes the determinants of individual attitudes towards environmental action by means of an original PLSPM model of Environmental Awareness-Social Capital-Action (EASCA). Estimates build on survey data on 34.612 individuals from 42 different countries, as provided in the fifth wave of the World Value Survey (2005-2009). Besides the benchmark global estimates, we perform subsample analysis for developed and developing countries, as well as country analyses for four major economies: China, India, Germany and the United States. Doing so allows us to underline structural differences between countries or main groups of countries. In particular, we find that environmental awareness and trust in not-forprofit organizations are the main determinants of individual action in support of environmentally friendly policies. The quality of environmental policymaking should improve if these cultural differences are better understood and taken into account.
\end{abstract}

Keywords: Environmental attitudes, Environmental policies, Development, Culture, Multivariate Analysis, Partial Least Squares.

JEL Classification Index: Q56, Q58, Z13 


\section{Introduction}

In the last twenty-five years, the international community has become aware that climate change, driven by massive emissions of greenhouse gases (GHGs), is a major risk for future generations (IPCC, 2014). Global warming is impacting the planet as a whole and can be tackled only by substantial international coordination, testing the ability of people, companies and governments to work together in fighting this major threat. How to distribute responsibilities between developed and developing countries is a contentious issue, since neither the causes nor the consequences of climate change are evenly distributed among countries.

Disparities across countries regarding not only their economic but also their geographical and demographic characteristics have been acknowledged in the successive negotiations within the United Nations Framework Convention on Climate Change (UNFCCC), which first stated the goal to stabilize the concentration of GHGs in the atmosphere as early as 1992. An important step ahead was reached during the $21^{\text {st }}$ Conference of the Parties (referred to as COP21) in December 2015 in Paris ${ }^{1}$, where both developed and developing countries decided to implement nationally determined contributions to the carbon mitigation effort. In this negotiation, developed countries agreed to provide financial and technological support to developing countries, "reflecting their common but differentiated responsibilities and respective capabilities, in the light of different national circumstances" (UNFCCC Secretariat, 2015, p. 23). For many observers, this agreement marked an important milestone in the fight against human-induced climate change, since for the first time, governments set aside their differences and agreed on the global target of keeping temperatures from rising by more than

\footnotetext{
${ }^{1}$ The agreement entered into force in November 2016, when 55\% of the UNFCCC participating countries ratified it.
} 
$2^{\circ} \mathrm{C}$. Furthermore, cities and companies (Hsu et al., 2016) are increasingly involved in the fight against climate change. However, the COP21 acknowledged that countries are different and might follow different paths to achieve the global goal, particularly as applied to measures to limit GHG emissions.

Nevertheless, the COP21 agreement is silent regarding countries' disparities in terms of environmental attitudes, beliefs and culture. Ultimately, the success of these measures and of international cooperation will depend on individuals' acceptance of environmental policies. Furthermore, research has discussed how the impact of attitudes on environmental action may be dependent on "socio-cultural constraints" that may impact the feasibility of ecological behavior, as Kaiser et al. (1999) discuss. Environmental attitudes of citizens, therefore, may be an important determinant of the success or failure of environmental policies in each country (Ziegler, 2015; Drews and van den Bergh, 2016).

One important determinant of citizens' responsible attitudes towards environmental policies is the level of environmental awareness (Bamberg and Möser, 2007; Hines et al., 1987). Differences in perceptions are grounded in the economic history of a given country (for instance, the relationship of the Japanese people to nuclear energy will bear the mark of the Fukushima disaster, Skea et al. 2013) and the economic and environmental education delivered in that country. Early studies investigating environmental preferences were carried out in the 1970s (Torgler and Garcia-Valinas, 2007). At that time, concern for the environment was explained as the expression of a change in human values in Western countries: when basic needs are fulfilled, human beings start to pursue "post-materialistic values", such as love and respect and intellectual and aesthetic goals, including care for the planet and future generations. It might be tempting to extrapolate and argue that awareness of 
environmental tensions should be greater in the developed world compared to the developing world, where many people still face extreme poverty. However, recent empirical studies reveal a convergence in the degree of awareness of environmental issues between developed and developing countries (Inglehart, 1995a, 1995b; Tjernström and Tietenberg, 2008; ).

In addition to awareness, social capital may also influence attitudes towards environmental policies because solutions to climate change involve subtler interactions among individuals, governments, communities and the private sector, among others, all of which should overcome strict marked-based transactions. Putnam (2001) referred to social capital as "connections among individuals - social networks and the norms of reciprocity and trustworthiness that arise from them." Indeed, a recent study by Carattini and Jo (2016) shows that societies whose members exhibit higher trust in people are more likely to engage in global cooperation by reducing their $\mathrm{CO} 2$ emissions. Yet, since the fight against climate change involves both governments and corporations, additional institutional factors related to trust in government (Tjernström and Tietenberg, 2008) and organizations (both for-profit and not-for-profit), as well as trust in technology, may help or hamper implementation of environmental policies (Drews and van den Bergh, 2016). However, to our knowledge, no encompassing analysis has been performed so far on the relative importance of each of these factors as drivers of attitudes towards environmental action. More importantly, little is known regarding whether these factors matter differently in developed and developing countries. This paper aims to fill this gap.

In particular, we ask the following questions. What cultural and attitude-based factors determine citizens' support for environmental policies? Are there significant differences in attitudes and their determinants in developing versus developed countries? Differences in 
perceptions, values (for example, care for nature) and attitudes may be culturally determined. If so, leveling the playing field across financial or technological factors may not be sufficient to effectively address the challenge of protecting nature, and culturally sensitive international cooperation is needed to devise solutions that respect these differences.

To address these questions, we develop an original Partial Least Squares path modeling (PLSPM) model of Environmental Awareness-Social Capital-Action (EASCA). The model allows for estimating the impact of five latent variables (environmental awareness, trust in people, trust in not-for-profit organizations, trust in for-profit organizations and trust in technology) on individual actions in support of the environment. The sample includes 34.612 individuals from a total of 42 countries, as provided in the 2005-2009 wave of the World Values Survey (WVS) (see WVS, 2008). The baseline model pools countries together. The model is then estimated separately for the group of developed and developing countries. Finally, we choose four key economies that are among the largest polluters, China, India, USA and Germany, to run the model at the country level.

Our findings can be summarized as follows. We find that environmental awareness and trust in not-for-profit organizations are the main determinants of individual action in support of environmentally friendly policies. Overall, trust in not-for-profit organizations plays a stronger role than environmental awareness, while trust in for-profit organizations is negatively related with support for environmental policies. The separate estimates of the EASCA for developing and developed countries reveal that that environmental awareness plays a stronger role in developed countries than developing countries. Trust in for-profit organizations is negatively related to support for environmental policies in the global sample, although this is not the case in India and China, where trust in firms is positively associated 
with positive attitudes towards environmental policies. In Germany and the US, on the other hand, trust in for-profit organizations is negatively related, while trust in non-profit organizations is positively related to environmental action. Also, in developed countries, trust in people is associated with stronger individual actions in support of the environment, while in developing countries, such action is associated with trust in technology.

Our analysis contributes, among others, to the policy discussions regarding the fair sharing of responsibilities between North and South countries. According to a broad specialist consensus, global warming is the outcome of the accumulation in the atmosphere of huge quantities of GHGs (carbon dioxide, methane, nitrous oxide), whose emissions rose exponentially after WW2 (IPCC, 2014). Large developed countries (US, Japan, EU15) no doubt bear the major responsibility for the stock of accumulated GHGs, and the criticism by emerging economies over their past "appropriation" of the atmosphere may be justified (Najam et al., 2003). Yet, as emphasized by Botzen et al. (2008), the relative contributions to the climate problem are changing dramatically, notably due to the rapid industrialization of China. In 2007, China overtook the USA in total annual CO2 emissions, accounting for $2 / 3$ of the world's increase in CO2 emissions since 2000; nevertheless, emissions per capita are still much higher in the US (Economist, 2015a, 2015b). These days, the share of carbon emissions emitted by the developed and the developing world is roughly equal, but the contribution of developing countries is expected to rise. Clearly, any attempt to control GHG emissions should be looked at the international level (Krugman, 2010).

The success of COP21 has been explained by many journalists and commentators as the result of each country being able to voluntarily decide its own target and mechanisms to achieve the target. Some experts have criticized the voluntary commitment mechanism on the grounds 
that many governments rely on reference periods with high GHG emissions, which makes the achievement of the target easier (Tirole, 2016). Our findings suggest that differences in attitudes and culture may explain why voluntary and country-specific commitments are a condition for success. Indeed, while policy makers may level the playing field regarding economic disparities thanks to cash transfer or subsidies, it is more difficult to do the same for attitudes and cultural views.

Our paper also contributes to the literature on the role trust plays in international coordination regarding global public goods. For instance, Carattini and Jo (2016) studied a set of countiries and found that a higher level of trust in people is more likely to be associated with reduced $\mathrm{CO} 2$ emissions. More generally, a vast body of literature has investigated how trust may impact the functioning of economic interactions. Following Kenneth Arrow's masterpiece "The Limits of Organization" (Arrow, 1974), economists began to acknowledge the fundamental role of interpersonal trust in the good functioning of market economies (inter alia, Algan and Cahuc, 2010; Dasgupta, 2000; Gambetta, 2000; McKean, 1975; Noreen, 1988). When, for one reason or another, the trust relationship among individuals is absent, transaction costs increase dramatically, and markets can no longer perform their role of smoothly allocating resources. Aghion et al. (2010) have noted that good institutions - those that protect individuals, ownership and contracts while granting the needed freedom to act can "produce" interpersonal trust. And in a virtuous circle, this large amount of trust provides the foundation for the optimal organization of markets. If we extrapolate their analysis to the difficult question of the environment, with pollution being a textbook case of production externality, societies where interpersonal trust is high can rely more on market-based regulatory mechanisms — such as trading $\mathrm{CO} 2$ emission rights, or carbon taxes - to achieve 
the desired targets, while societies where interpersonal trust is low should use more-coercive measures (norms, limitations, quotas, etc.).

Corruption may be especially detrimental in developing countries (Mauro, 1995; North, 1990) and could explain citizens' low confidence in the ability of their governments to address the environmental problem efficiently. This would also explain why they would rely more on NGOs. Two main types of policy exist: market based solutions and command and control. Whatever the type of measure, it is important to consider whether the government can be trusted to take the right actions. Governments pursue their own political goals, and political goals are short-term, particularly compared to centenary environmental cycles. To achieve GHG reduction targets, governments must impose costs on the population, and in democracies, politicians might be reluctant to do so before the "next election". Public support and trust in the government might facilitate the adoption of less-popular measures.

Besides the government, non-profit organizations (NGOs; media, including Internet; associations) can make an important contribution to the protection of the environment by sharing information, educating consumers or lobbying for eco-friendly technologies and consumption modes. One should not neglect the power of education in raising awareness about the environmental risks of inaction.

In the capitalist world, companies are the main engines of growth. They serve society by producing goods and services demanded by consumers, they create jobs and investment opportunities, and they innovate. While all companies consume energy, and in so doing, contribute to the production of GHGs, some sectors are disproportionally contributing to GHG emissions. In particular, the utilities, materials and energy sectors are among top 
emitting sectors, and fossil fuel and cement companies have been historically large contributors to cumulated emissions (Hsu et al., 2016). Regulations enforced by governments oblige firms to internalize the costs of GHG emissions and can ban technologies or products that generate GHGs, particularly when cost-efficient alternative solutions are available. At the same time, corporate social responsibility (CSR), with initiatives such as the CDP (carbon disclosure project), may drive corporate change (Winston, 2010). Furthermore, in developed countries, differences in institutional and regulatory frameworks have determined different visions of CSR, with a notable divide between the US and European countries (Matten and Moon, 2008).

Finally, we also contribute to understanding how values and beliefs regarding technology may impact policy-making. Trust in technology reflects individual optimism about the ability of scientific progress to address and solve social challenges, from starvation and poverty to space exploration. Recently, enthusiasm is somehow regressing toward "more ambivalent stances", at least in Europe (Kerschner and Ehlers, 2016). In the environmental domain, technological progress has contributed to continuous reductions in the cost of producing energy from renewable sources (mainly solar) and, for many authors, it can be solution for a clean planet (von Weizsäcker et al. 2009). It has already dramatically contributed to the reduction of the amount of energy per unit of GDP in the last forty years. So far, however, this progress has been slow, and there is no major technological disruption in sight (such as nuclear fusion). Moreover, it is driven by variation in the cost of raw materials. Research on solar energy is more intensive when the oil barrel costs $100 \$$ than when it costs $50 \$$. Forty years from now, few (if any) Sci-Fi authors will have foreseen the huge development of IT communication and the digital economy; if this is true, it is likely that no one can know what technological progress can shape the future in 2030. In this respect, beliefs and attitudes with 
respect to technology, whether grounded in the hard facts of science or not, play an important role in the decision of whether to act against the immediate deterioration of the environment. Too-strong beliefs in technology (and science) can negatively affect pro-environmental behavior, insofar as people would rely on uncertain future discoveries to remove environmental risks, activating a responsibility diffusion mechanism (Borden, 1984).

This paper is structured as follows. Section 2 presents the structural model, describes the data and defines the LVs. Section 3 presents the baseline results. Section 4 presents separate estimates of the model for the developed and developing countries. Section 5 presents moredetailed estimates for four main economies: China, India, the USA and Germany. Section 6 concludes.

\section{Methodology}

\subsection{The Model}

Our aim is to investigate the determinants of individuals' attitudes toward pro-active environmental policies and to study the possible country differences, grounded in their specific contexts.

To do so, we use Partial Least Squares path modeling (PLSPM) to estimate an original Environmental Awareness-Social Capital-Action (EASCA) model with data issued from the fifth wave (2005-2009) of the World Values Survey (WVS). The WVS is a non-commercial, cross-national investigation of human beliefs based on nationally representative surveys conducted in almost 100 countries, using a common questionnaire. 
Most relevant for our analysis, the WVS provides information on individuals' stated willingness to support environmental policies and on several important cultural factors, including social capital and environmental awareness, which can lead to a favorable attitude toward environment policies. In contrast to more-recent waves ${ }^{2}$, the 2005-2009 wave provides a richer set of indicators concerning individual attitudes towards environmentally friendly policies.

Concepts such as social capital, awareness and environmental action cannot be captured by a single indicator/variable. Our methodology consists in developing a set of relevant latent variables (LVs), each being related to a relevant factor that cannot be measured directly. Partial Least Squares path modeling (PLSPM) enables these complex concepts to be measured by exploiting the information provided by sets of manifest variables (MVs) that are directly observed. It then analyzes networks of linear predictive relations between LVs that refer to such concepts.

PLSPM represents a well-established component-based approach to Structural Equation Modeling that is based on the construction of composites as linear combinations of the MVs corresponding to each $\mathrm{LV}^{3}$. Therefore, a PLS path model is composed of two sub-models: a measurement model relating each set of MVs to the LV they are expected to measure and a structural model connecting the LVs to each other according to a theory-based network of predictive relationships.

\footnotetext{
2 The sixth wave was completed in 2014, and the collection of data for the $7^{\text {th }}$ wave started in 2016.

${ }^{3}$ See, for instance, Wold (1985) and Esposito-Vinzi et al. (2010).
} 
In this methodological framework, the individual actions of LVs are driven by five explanatory variables, which are also LVs: one of them is related to environmental awareness, and the other four are related to social capital. We next discuss each in detail.

The awareness LV measures individuals' knowledge and concern about environmental degradation; it is explained by two components: local awareness, which is related to morevisible "neighborhood" environmental risks (water and air pollution, for instance), and global awareness, which is related to macro environmental risks (including global warming and GHG emissions). Capturing awareness is important because public policy campaigns in the fight against climate change are often geared towards increasing awareness based on the idea that society cannot address a problem that is not publicly known. Nevertheless, considering awareness is insufficient to explain a favorable attitude towards environmental policies.

Attitudes are grounded in the deeper structure of the social capital of a given country, which itself includes various dimensions of trust. To capture these dimensions, we use trust in people, trust in non-profit organizations, trust in for-profit organizations and trust in technology. Because environmental policies may involve environmental taxes or accepting higher costs, which are tantamount to giving up income, they are partly related to individual trust in the organizations called to implement them: governments and non-governmental organizations (NGOs). For this reason, the model includes trust in non-profit organizations as an explanatory latent variable. In the last few decades, a huge majority of large companies have incorporated the notion of Corporate Social Responsibility as a key element of their production and development strategy, including environmentally friendly policies. If individuals increasingly rely on these companies to take over environmental friendly actions, individual direct action might be less useful. To test for this assumption, the model will 
include trust in for-profit organizations as an LV. A last LV is trust in technology; indeed, if individuals believe that technological innovation will provide the needed solutions to fight climate change, this might also diffuse their own responsibility.

In developing the model, we use a parsimonious approach where each of these latent variables contributes to attitudes towards individual action in a similar way. Fig. 1 presents the structural form of the EASCA model.

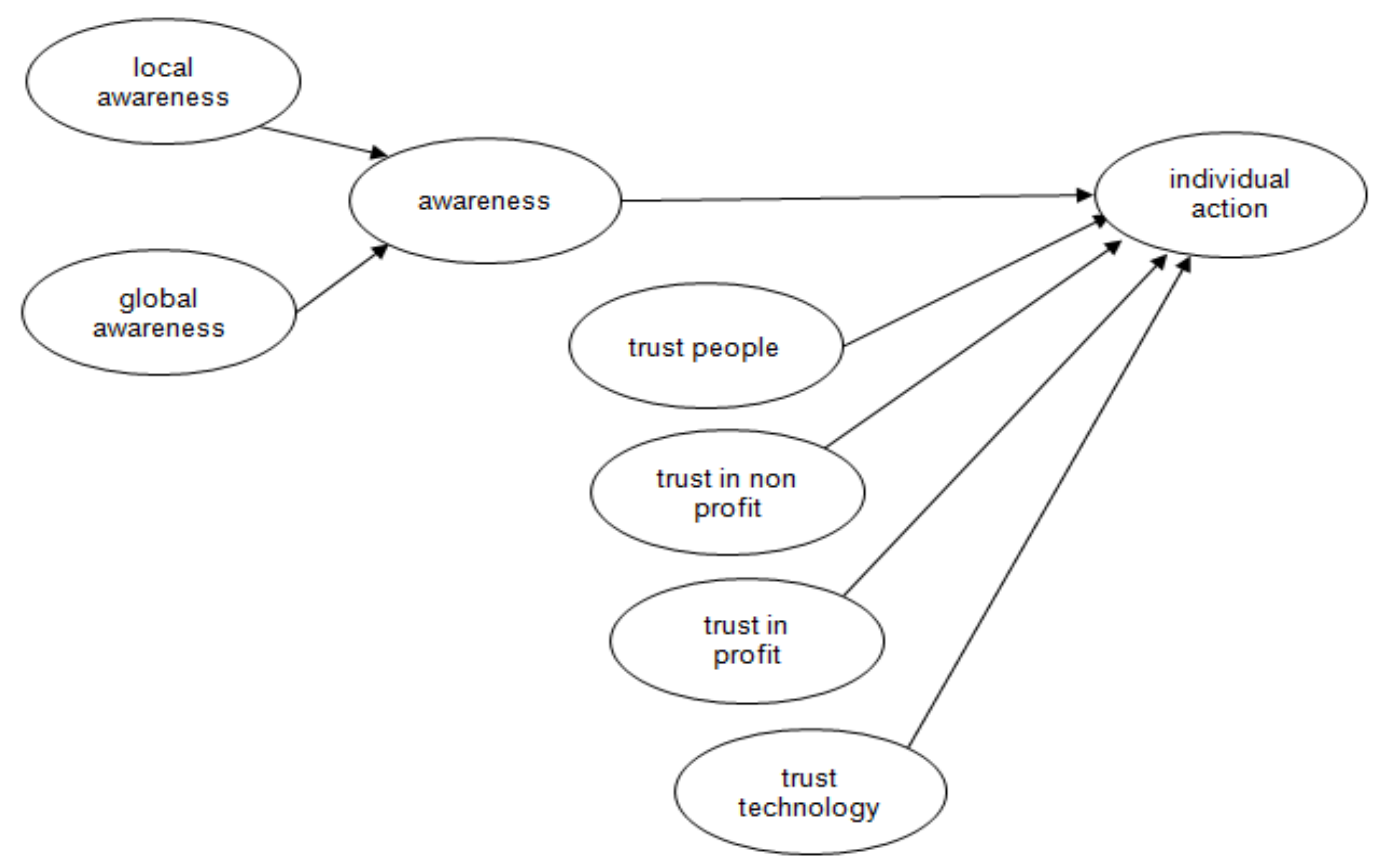

Fig. 1. The Structural part of the EASCA Model.

Different kinds of epistemological relationships between each LV and its own MVs can be adopted, depending on the conceptual definition of the specific LV in the measurement model. Two possible relationships are usually defined: an outwards-directed measurement (also known as reflective), where the MVs are meant to describe the concept and be caused by the corresponding LV; and an inwards-directed measurement (also known as formative), where the MVs are meant to contribute to the corresponding LV that is an effect of its own 
MVs. In both cases, the scores of an LV are obtained by means of a linear function of its own MVs. The weights are determined differently in the two measurement models, as they have a different objective to attain. In both cases, the scores of the LV are provided by a linear function of its MVs, whose coefficients are named outer weights and measure the importance of each MV in the definition of the corresponding LV.

The measurement model in this paper is specified as being outwards-directed for all LVs except "Individual actions in favor of environmental policy". For the latter, the MV's income and taxes are meant to be different elements leading to people's actions, while the MVs corresponding to the other LVs are meant as correlated elements reflecting people's opinions.

The whole PLSPM algorithm is based on simple and multiple linear regressions for estimating the outer weights (and loadings) between MVs and the corresponding LVs in the measurement model and for estimating path coefficients between the connected LVs in the structural model. The non-parametric nature of PLSPM implies that model assessment and validation are performed via a bootstrap-based procedure that provides confidence intervals and p-values for inferring model parameters and quality indexes.

\subsection{Data and the latent variables}

As already mentioned, our dataset includes answers to relevant questions asked by the fifth wave of the World Value Survey. After removing missing data, which are quite frequent in this survey, the final dataset includes 34.612 individuals from 42 countries; 16 belong to the group of developed countries as defined by the UN IPCC country classification 2015, and the 
rest are developing countries. ${ }^{4}$ The sample has an equal gender distribution $(49 \%$ of the respondents are women), with a clear prevalence of respondents over 24 years old ( $82 \%$ of the respondents) and who are quite educated (68\% of the respondents reported a higher education degree). Finally, $75 \%$ of the respondents belong to the lower $70^{\text {th }}$ decile of the income distribution in their respective countries.

Table 1 presents the list of the questions (MVs) selected for the construction of the LVs.

The last column indicates the scale of each manifest variable. It is worth mentioning that the attributes of the scales differ across MVs, being tuned to achieve the maximum meaningfulness. Individuals' awareness about environmental issues is evaluated by questioning how serious they perceive the problem to be. Trust in for-profit organizations and trust in non-profit organizations are measured by asking how much confidence the respondent has in each type of organization: "none at all", "not very much", "quite a lot", or " a great deal". On the other hand, Trust in technology and individual actions in support of the environmental policy are measured through a classical Likert scale, where the maximum indicates full agreement. Trust in people is measured by a dummy variable taking the value 1 if the answer is affirmative, and 0 otherwise. All variables have the same polarity: higher values of the measure (whatever the scale) correspond to higher approval rates (higher awareness, higher trust, higher willingness-to-act). This scaling is important because it allows a simpler and more straightforward interpretation, and it leads to all-positive correlations between MVs corresponding to the same LV, thus enabling the computation of scores for a composite indicator.

\footnotetext{
${ }^{4}$ The exercise of grouping countries in two categories is extremely difficult. The UN-IPCC does not rely solely on GDP but on many other variables, including political and societal variables.
} 
In the multivariate analysis (from Section 3 ahead), the MVs will be standardized such that all indicators will have zero means and variances equal to 1.

Table 1. MVs and LVs.

\begin{tabular}{|c|c|c|c|}
\hline $\mathrm{LV}$ & MV & Question & Scale \\
\hline \multirow[t]{3}{*}{$\begin{array}{l}\text { Local } \\
\text { awareness }\end{array}$} & la1 & $\begin{array}{l}\text { Environmental problems in your community: Poor water } \\
\text { quality }\end{array}$ & $\begin{array}{l}1-4 \\
\text { not serious at all } \rightarrow \text { very serious }\end{array}$ \\
\hline & la2 & $\begin{array}{l}\text { Environmental problems in your community: Poor air } \\
\text { quality }\end{array}$ & $\begin{array}{l}1-4 \\
\text { not serious at all } \rightarrow \text { very serious }\end{array}$ \\
\hline & la3 & $\begin{array}{l}\text { Environmental problems in your community: Poor } \\
\text { sewage and sanitation }\end{array}$ & $\begin{array}{l}1-4 \\
\text { not serious at all } \rightarrow \text { very serious }\end{array}$ \\
\hline \multirow[t]{3}{*}{$\begin{array}{l}\text { Global } \\
\text { awareness }\end{array}$} & ga1 & $\begin{array}{l}\text { Environmental problems in the world: Global warming or } \\
\text { the greenhouse effect }\end{array}$ & $\begin{array}{l}1-4 \\
\text { not serious at all } \rightarrow \text { very serious }\end{array}$ \\
\hline & ga2 & $\begin{array}{l}\text { Environmental problems in the world: Loss of plant or } \\
\text { animal species or biodiversity }\end{array}$ & $\begin{array}{l}1-4 \\
\text { not serious at all } \rightarrow \text { very serious }\end{array}$ \\
\hline & ga3 & $\begin{array}{l}\text { Environmental problems in the world: pollution of rivers, } \\
\text { lakes and oceans }\end{array}$ & $\begin{array}{l}1-4 \\
\text { not serious at all } \rightarrow \text { very serious }\end{array}$ \\
\hline $\begin{array}{l}\text { Trust in } \\
\text { people }\end{array}$ & $\begin{array}{l}\text { t_peopl } \\
\text { e }\end{array}$ & $\begin{array}{l}\text { Most people can be trusted or we need to be very careful } \\
\text { in dealing with people }\end{array}$ & $\begin{array}{l}\text { 1: Most people can be trusted } \\
0: \text { Need to be very careful }\end{array}$ \\
\hline $\begin{array}{l}\text { Trust in for- } \\
\text { profit org. }\end{array}$ & t_p1 & Confidence: Major companies & $\begin{array}{l}1-4 \\
\text { none at all } \rightarrow \text { lot of confidence }\end{array}$ \\
\hline \multirow[t]{2}{*}{$\begin{array}{l}\text { Trust in non- } \\
\text { profit org. }\end{array}$} & t_no_p1 & Confidence: The Government & $\begin{array}{l}1-4 \\
\text { none at all } \rightarrow \text { lot of confidence }\end{array}$ \\
\hline & t_no_p2 & Confidence: The Environmental Protection Movement & $\begin{array}{l}1-4 \\
\text { none at all } \rightarrow \text { lot of confidence }\end{array}$ \\
\hline \multirow[t]{3}{*}{$\begin{array}{l}\text { Trust in } \\
\text { technology }\end{array}$} & tech1 & $\begin{array}{l}\text { Science and technology are making our lives healthier, } \\
\text { easier and more comfortable }\end{array}$ & $\begin{array}{l}1-10 \\
\text { completely disagree } \rightarrow \text { completely } \\
\text { agree }\end{array}$ \\
\hline & tech2 & $\begin{array}{l}\text { Because of science and technology, there will be more } \\
\text { opportunities for the next generations }\end{array}$ & $\begin{array}{l}1-10 \\
\text { completely disagree } \rightarrow \text { completely } \\
\text { agree }\end{array}$ \\
\hline & tech3 & The world is better off because of science and technology & $\begin{array}{l}1-10 \\
\text { completely disagree } \rightarrow \text { completely } \\
\text { agree }\end{array}$ \\
\hline \multirow{2}{*}{$\begin{array}{l}\text { Individual } \\
\text { actions in } \\
\text { support of } \\
\text { envir. policy }\end{array}$} & income & Would give part of my income for the environment & $\begin{array}{l}1-4 \\
\text { strongly disagree } \rightarrow \text { strongly agree }\end{array}$ \\
\hline & taxes & $\begin{array}{l}\text { Increase in taxes if used to prevent environmental } \\
\text { pollution }\end{array}$ & $\begin{array}{l}1-4 \\
\text { strongly disagree } \rightarrow \text { strongly agree }\end{array}$ \\
\hline
\end{tabular}

The following bar-charts show the distribution of the observed MVs for each LV. Both the environmental problems in the community and in the world (Fig. 2) are perceived as very important by most of the respondents. Somewhat surprisingly, the surveyed persons express a stronger concern for global awareness items than for local awareness items. 

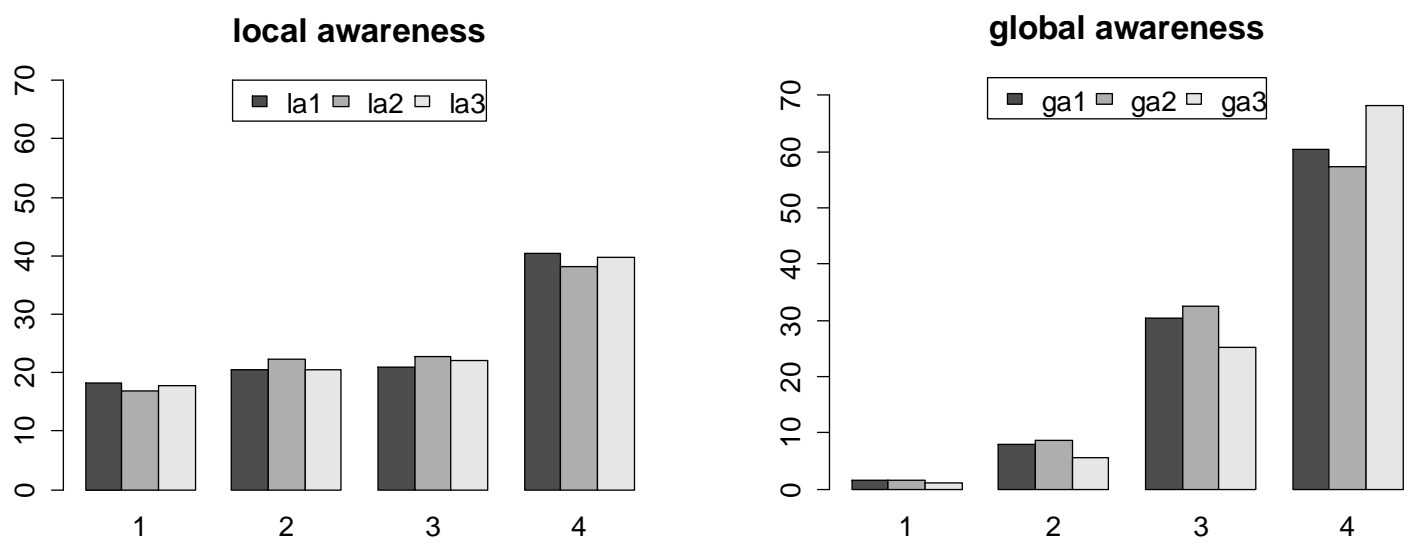

Fig. 2. Distribution of the MVs related to local (left-hand side) and global (right-hand side) awareness.

As shown in Figure 3, people do not take on extreme positions regarding trust in for-profit organizations and in not-for-profit organizations.
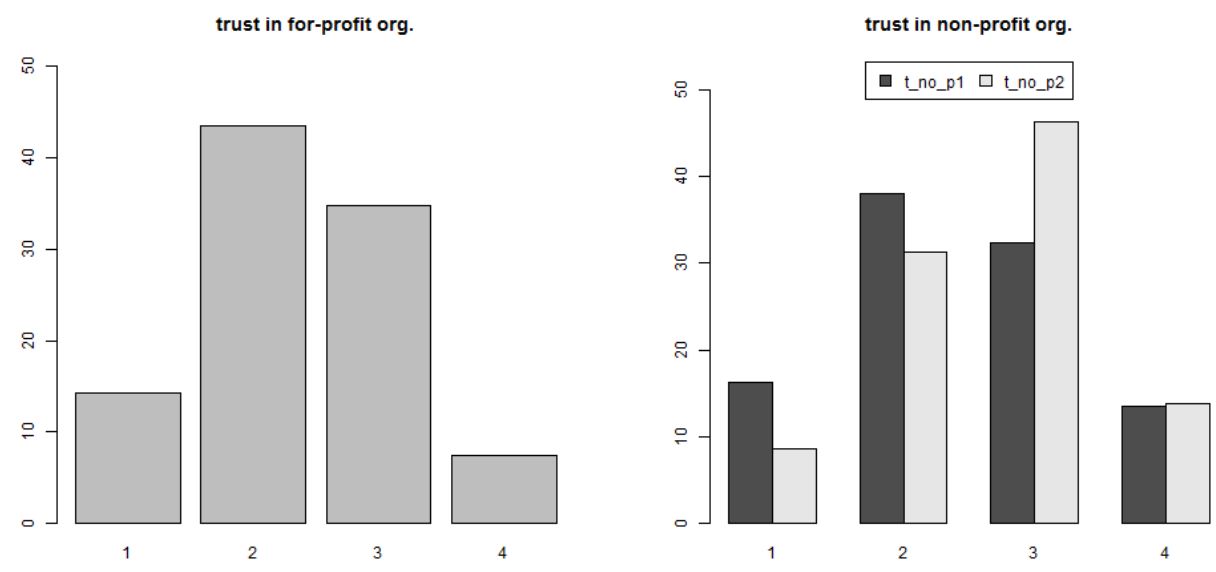

Fig. 3. Distributions of the MVs related to trust in for-profit organizations (left-hand side) and trust in non-profit organizations (right-hand side).

With respect to trust in technology (Fig. 4), a majority of persons express high confidence in technology, as measured by answers to questions tech1, tech2 and tech3. Recall that scores 
above (below) 5 are representative of trust (distrust) in the different dimensions in technology. Overall, the distributions of the responses are all skewed toward trust in technology.

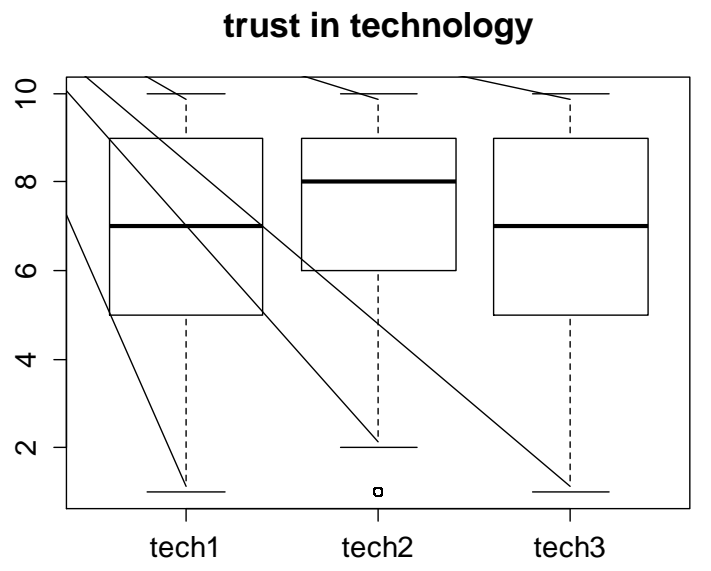

Fig. 4. Distributions of the MVs related to trust in technology.

With respect to trust in people, only $27 \%$ of the surveyed individuals believe that most people can be trusted, while all the others answered that we need to be very careful in dealing with people.

Turning to the action variables, most of the people are willing to personally support the environmental policies by sharing their income or paying more taxes (Fig. 5).] 


\section{individual actions}

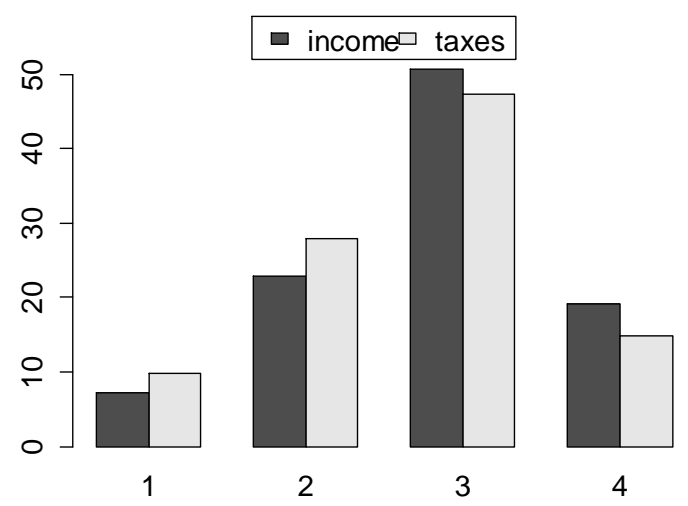

Fig. 5. Distribution of the MVs related to individual action in support of environmental policies.

As we already mentioned, our analysis requires the construction of four reflective LVs. A reflective LV is meant to be unidimensional in the sense of factor analysis. To check for unidimensionality, for each block of MVs corresponding to an LV, we look at results from the PCA (the $1^{\text {st }}$ eigenvalue is expected to be the only one greater than 1 and much higher than the second one). To check the internal consistency of each block of MVs, we look at the Cronbach's $\alpha$ and Dillon-Goldstein's $\rho$, which need to be greater than 0.7. Table 2 shows that four blocks are unidimensional, and all of them are internally consistent. Awareness naturally has two dimensions, as this LV combines local and global awareness. Statistics for trust in profit and trust in people are not shown, as each of these blocks consists of a single MV.

Table 2. Check for MV block unidimensionality.

\begin{tabular}{|l|c|c|c|c|c|}
\hline LV & $\begin{array}{c}\text { Number of } \\
\text { MVs }\end{array}$ & $\begin{array}{c}\text { Cronbach's } \\
\alpha\end{array}$ & $\rho$ D.G. & $\begin{array}{c}\text { 1st } \\
\text { eigenvalue }\end{array}$ & $\begin{array}{c}\text { 2nd } \\
\text { eigenvalue }\end{array}$ \\
\hline local awareness & 3 & 0.900 & 0.938 & 2.500 & 0.269 \\
\hline global awareness & 3 & 0.809 & 0.887 & 2.173 & 0.478 \\
\hline awareness & 6 & 0.789 & 0.850 & 2.941 & 1.735 \\
\hline trust non-profit & 2 & 0.491 & 0.797 & 1.325 & 0.675 \\
\hline trust technology & 3 & 0.678 & 0.825 & 1.862 & 0.826 \\
\hline
\end{tabular}




\section{The all-country estimate of the EASCA model}

The baseline model is the estimate of the EASCA structural model (Fig. 1) using the whole set of individual observations collected from the 42 countries.

Legend: $* * *$ significant at $1 \%, * *$ significant at $5 \%, *$ significant at $10 \%$ shows the coefficients relating each MV to the corresponding LV, namely, the outer weights. They can be interpreted as regression coefficients measuring the impact of a unitary increase of a given MV on the corresponding LV. All the coefficients but tech2 are significant at the 0.01 level (significance is obtained using the classical t-test).

With respect to the local awareness LV, respondents assign the highest weight to "poor air quality" (la2) compared to poor water quality and poor sewage and waste management. The three MVs responsible for the global awareness LV (global warming, loss of bio-diversity, pollution) have rather similar weights. Trust in non-profit organizations is mainly explained by the confidence in the NGOs (Environmental protection movement) (t_no_p2) as compared to trust in the Government (t_no_p1), while respondents' perception of the welfare improvements to be expected from science and technology (tech3) has the highest impact on trust in technology.

Table 3. Outer weights - coefficients relating the MVs to the corresponding LV.

\begin{tabular}{|l|l|l|}
\hline \multicolumn{1}{|c|}{$\mathbf{L V}$} & \multicolumn{1}{|c|}{ MV } & \multicolumn{1}{c|}{$\begin{array}{c}\text { Outer } \\
\text { weight }\end{array}$} \\
\hline \multirow{2}{*}{$\begin{array}{l}\text { individual } \\
\text { action }\end{array}$} & income & $0.569 * * *$ \\
\cline { 2 - 3 } local awareness & taxes & $0.540 * * *$ \\
\cline { 2 - 3 } & la1 & $0.276 * * *$ \\
\cline { 2 - 3 } & la2 & $0.474 * * *$ \\
\cline { 2 - 3 } & la3 & $0.344 * * *$ \\
\hline
\end{tabular}




\begin{tabular}{|c|c|c|}
\hline \multirow{3}{*}{$\begin{array}{l}\text { global } \\
\text { awareness }\end{array}$} & ga1 & $0.353 * * *$ \\
\hline & ga2 & $0.393 * * *$ \\
\hline & ga3 & $0.427 * * *$ \\
\hline \multirow{2}{*}{$\begin{array}{l}\text { trust in non- } \\
\text { profit org. }\end{array}$} & t_no_p1 & $0.448 * * *$ \\
\hline & t_no_p2 & $0.760 * * *$ \\
\hline \multirow{3}{*}{$\begin{array}{l}\text { trust } \\
\text { technology }\end{array}$} & tech1 & $0.438 * * *$ \\
\hline & tech2 & 0.176 \\
\hline & tech3 & $0.664 * * *$ \\
\hline
\end{tabular}

We can now explore the path coefficients of the various reflexive LVs on the individual actions in support of environmental policies. As shown in Fig. 1, this LV is the key outcome variable in the EASCA model.

The general concept of awareness relies equally on the local and global awareness LVs (their path coefficients are respectively 0.693 and 0.564 ). As expected, this awareness has a positive impact on the individual action LV (Legend: *** significant at 1\%, ** significant at 5\%, * significant at $10 \%$

). Trust in non-profit organizations (with their high load on NGOs) also has a positive impact on individual action. This relationship is not surprising; persons who trust in NGOs will also favor policies in favor of the environment. Respondents who trust for-profit organizations express a lower motivation to act in support of the environment. This negative relationship can be understood if these individuals feel as though they are transferring some of their environmental responsibilities onto companies. This "responsibility shift" appears to be an important blocking factor of the pro-environment action. However, a similar responsibility shift cannot be observed with respect to technology. As shown by the latter coefficient, trust in technology has a positive impact on individual action. This may reflect positive attitudes towards the future and the ability of human behavior (via science or political action) to shape nature. 
Table 4. Path coefficients for individual actions.

\begin{tabular}{|c|c|}
\hline LV & $\begin{array}{c}\text { Path } \\
\text { coefficient }\end{array}$ \\
\hline awareness & $0.160 * * *$ \\
\hline trust people & $0.062 * * *$ \\
\hline trust non-profit org. & $0.208 * * *$ \\
\hline trust in for-profit org & $-0.030 * * *$ \\
\hline trust technology & $0.039 * * *$ \\
\hline $\mathrm{R} 2$ & 0.074 \\
\hline
\end{tabular}

While the path coefficients are all significant and show that our key LVs are all relevant in explaining individual action, the model presents a modest R2. This is the case for other survey-based attitude studies as well. Our data set does not include other important determinants of individual action.

One explanation for the modest R2 may be that our estimation pools all countries together. Since our focus is on cultural attitudes, the relations we explore may themselves be culturally dependent and differ across countries, for example, along the developed vs. developing divide. As shown by Kaiser et al. (1999), the relation between attitudes and behavior may be constrained by socio-cultural variables that may be country specific. Along these lines, some of our variables may mean different things to individuals in different countries with different histories. These reasons motivate us to further explore our model in two directions. First, we estimate the separately for developed and developing countries. Second, we perform and 
compare a country-level analysis for countries that are among the largest polluters and for which our model has explanatory power (R2 larger than 0.1$)$.

\section{The EASCA model and the developed vs. developing countries environmental}

\section{divide}

As stated in the introduction, while both developing and developed countries tend to agree on the need for urgent changes in order to favor sustainable growth, they express deep divergences with respect to solutions. Our model will show that some of these divergences are grounded in an attitude divide between the two groups of countries. To do so, in this section, we will take advantage of the fact that our sample includes 25 developing and 17 developed countries (as defined by UN IPCC Classification 2015, in the Appendix, Table A1).

Fig. 6 shows the outer weights obtained for the whole set of countries (All) and for the two subsets, Developing and Developed, countries. Numerical values and information about the statistical significance of the coefficients are shown in the Appendix. The coefficients reveal differences among the two groups of countries in terms of intensity and even the sign of the values. Indeed, the contribution of (tech 1) and (tech 2) MVs to the LV trust in technology is negative in the developed countries, while it turns positive in the developing countries. In countries such as China and India, technological leaps and progress have been important engines of growth and prosperity; it is not surprising, then, to see that optimism about the ability of technology to tackle the environmental challenge is high in those countries. By contrast, in developed countries, which had to overcome the New Economy (or Dotcom) crisis (2000-2001), individuals shared some disenchantment with technological revolutions. 
In terms of individual action in support of environmental policies, compared to developing countries, citizens in the rich world are more reluctant to increase their tax burden, probably because in these countries, taxes are already high, or just because political debates keep taxes at the center of the stage as a topical issue. In the individual action LV, the two main items thus have different relative weights from one group of countries to the other.
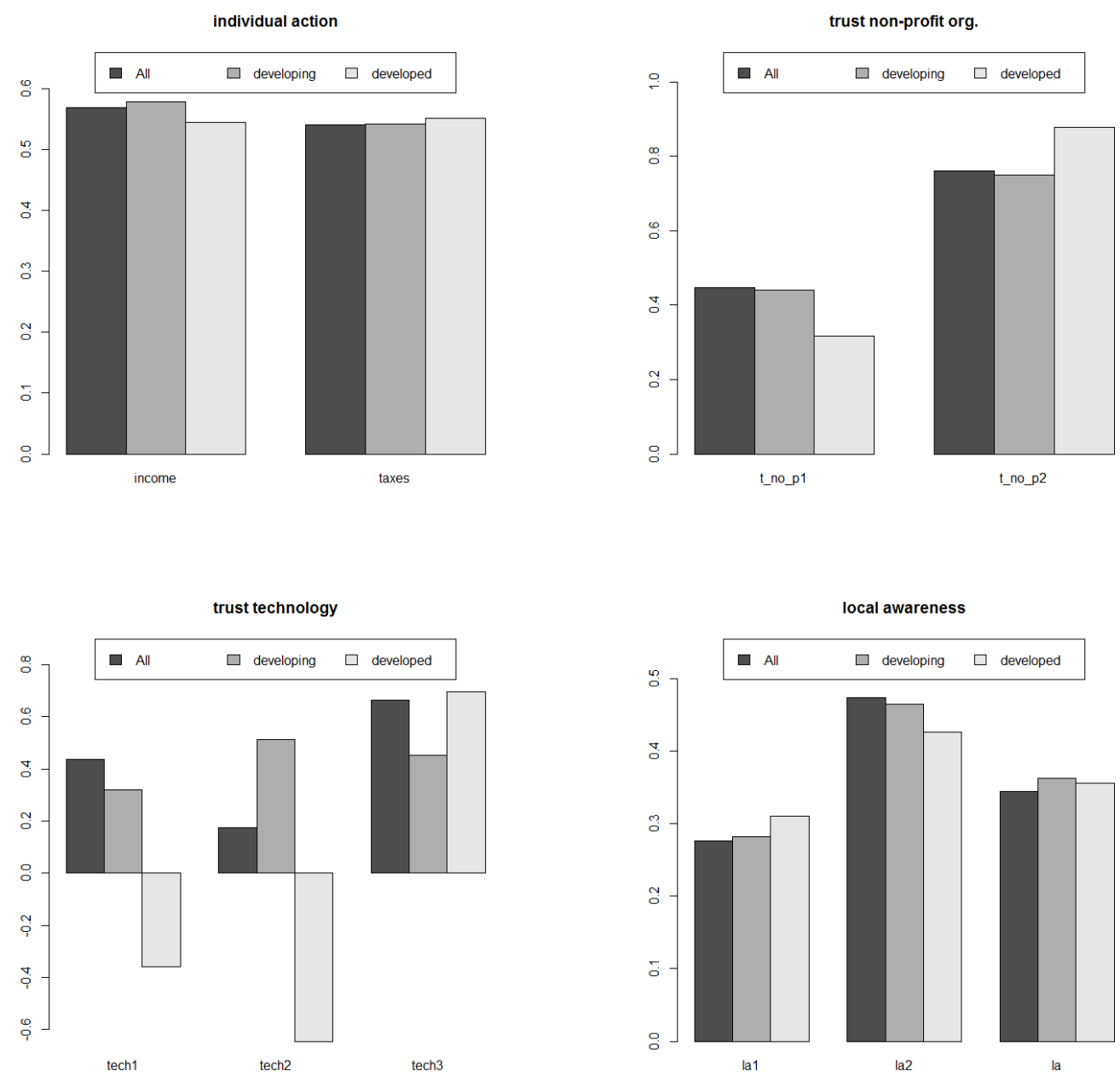


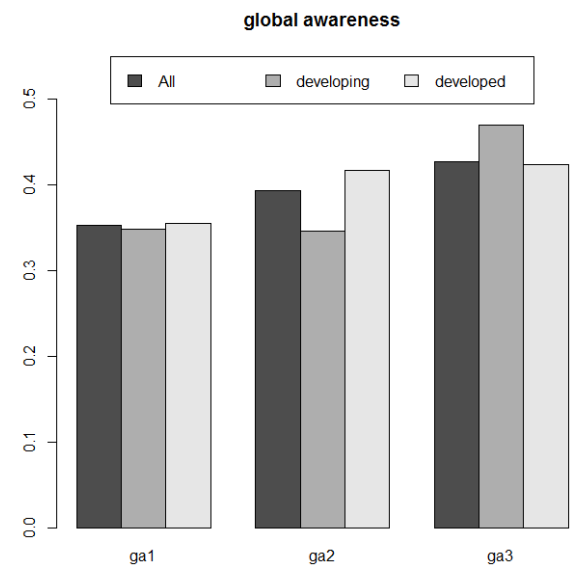

Fig. 6. Distribution of the outer weights for each LV: whole sample, developed and developing countries.

Legend: $* * *$ significant at $1 \%, * *$ significant at $5 \%, *$ significant at $10 \%$ presents the contribution of the explanatory LVs to the individual environmental actions LV for all countries (the same as in Legend: *** significant at $1 \%$, ** significant at $5 \%$, * significant at $10 \%$

) and separately for the two groups. The signs of the coefficients are the same, yet their intensity is different. Awareness, trust in people and trust in non-profit organizations appear to be stronger drivers of individual action in the developed countries compared to the developing ones.

The relationship between awareness and individual action is stronger in the developed countries, which is expected if we consider that developing countries must find a way to protect the environment while at the same time creating conditions of high economic growth to catch up with the developed countries. 
Trusting for-profit organizations to implement environmentally friendly policies has no significant impact in the developing countries, while it has a strong and significant negative impact on individual action in the rich countries. In the developed countries, companies have been running communication campaigns for at least twenty years that emphasize corporate actions in favor of the environment to answer a social call for higher corporate social responsibility. If individuals in these countries believe that companies effectively take the lead in the fight against environmentally harmful policies, they might want to reduce their own action.

Trust in technology has the same positive effect in both groups of countries, yet we know that the corresponding latent variable is defined differently in the two groups: in developed countries, the MVs tech 1 and tech 2 have a negative loading, while tech 3, which is more future oriented, has a positive loading.

Table 5. Path coefficients for individual actions: all countries and developing and developed countries.

\begin{tabular}{lcrrr}
\hline LV & All & Developing & Developed & p-value \\
\hline awareness & $0.160 * * *$ & $0.118 * * *$ & $0.173 * * *$ & 0.010 \\
trust people & $0.062 * * *$ & $0.060^{* * *}$ & $0.115^{* * *}$ & 0.010 \\
trust in non-profit org & $0.208 * * *$ & $0.162 * * *$ & $0.245^{* * *}$ & 0.010 \\
trust technology & $0.039 * * *$ & $0.069 * * *$ & $0.053 * * *$ & 0.158 \\
trust in for-profit org & $-0.030 * * *$ & -0.011 & $-0.045 * * *$ & 0.010 \\
\hline \multicolumn{4}{c}{0.053} \\
\hline R2 & 0.074 & 0.112 \\
\hline \multicolumn{4}{c}{ Legend: $* * *$ significant at 1\%,** significant at 5\%, * significant at 10\% }
\end{tabular}

From an inferential point of view, it is possible to evaluate whether, for developing and developed countries, differences between path coefficients are statistically significant. The last column in Table 5 displays for each path coefficient the p-values of a permutation test on 
the equality between the coefficients. Low p-values mean the coefficients are significantly different between the two groups of countries.

Differences in the R2 coefficients $(0.053$ vs. 0.112$)$ would suggest that the EASCA model is a better fit for explaining the drivers of environmental action in the group of developed countries. As a robustness check, we estimate the EASCA model for each of the 42 countries in our sample. Fig. 7 presents the R2 of the estimated model for each country. It can be seen that 13 out of 42 models present an R2 greater than 0.1 . These 13 countries include both developed and developing countries. We conclude that the observed difference in the R2 for developed and developing countries in Table 4 stems essentially from the composition effect.

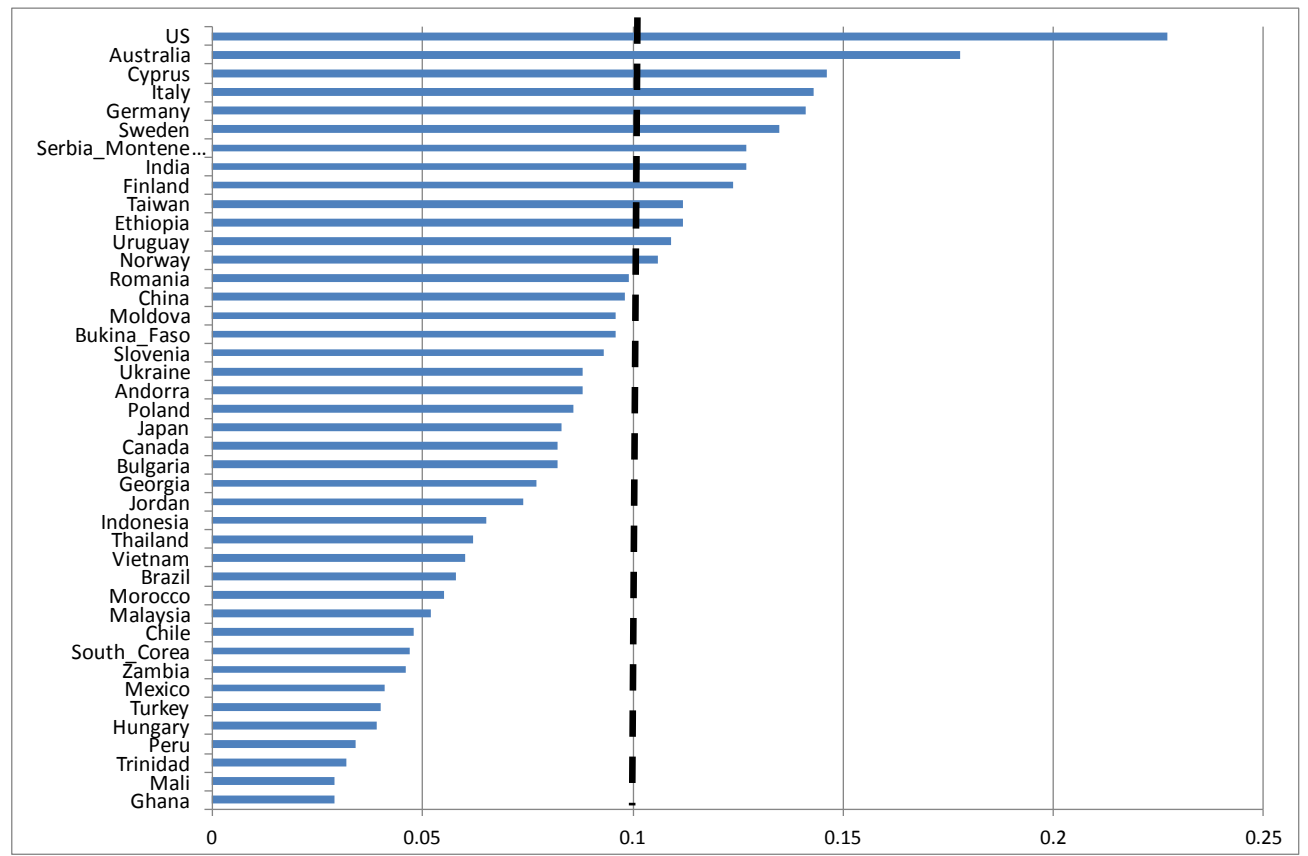

Fig. 7. Country-specific R2 coefficients of the EASCA estimates. The vertical dotted line represents the 0.10 threshold in the $\mathrm{R} 2$ coefficients.

In the next step, we check whether countries can be gathered into a few groups based on the information provided by the EASCA modeling phase. To do so, we construct a matrix of the 
path coefficients yielded by each country-based model, where the rows are the countries and the columns correspond to the five LVs' coefficients explaining the individual action LV. ${ }^{5}$ This matrix is then submitted to a principal component analysis (PCA) in order to explain this pattern in terms of the most impactful LVs (Fig. 8), and to represent the pattern of differences/similarities between countries (Fig. 9).

The factorial plane in Fig. 8 explains $55 \%$ of the total variation across countries in our five path coefficients. The first axis mainly captures the tension between trust in non-profit organizations and trust in for-profit organizations, which, we have shown, is representative of an important cultural divide between developing and developed countries. ${ }^{6}$ The second axis opposes awareness to all the variables measuring "trust", mainly to trust in people and trust in technology. In general, developing countries will express higher "trust" but relatively lower awareness; this makes interpretation of the vertical axis more difficult.

\footnotetext{
${ }^{5}$ The results must be interpreted with caution because the data in each row are obtained with a different model.

${ }^{6}$ As shown in this section, citizens in the developed world trust more in non-profit organizations (mainly NGOs), while citizens in developing countries trust more in for-profit organizations.
} 


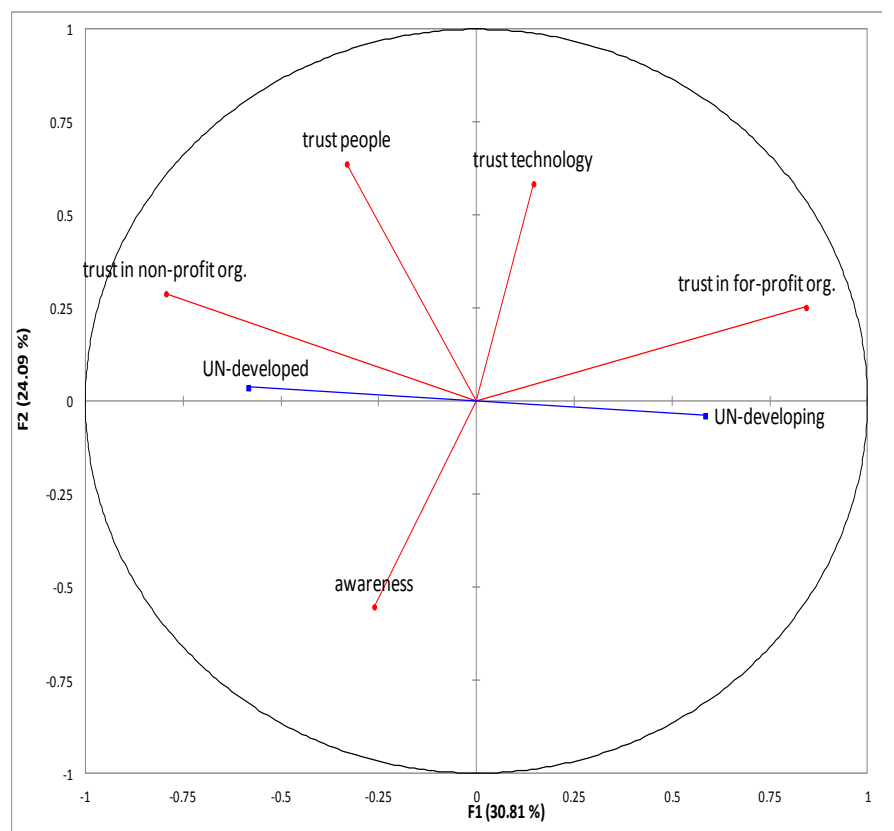

Fig. 8. Representation of the path coefficients on the first factorial plane.

Fig. 9 represents our 42 countries in this factorial plane.

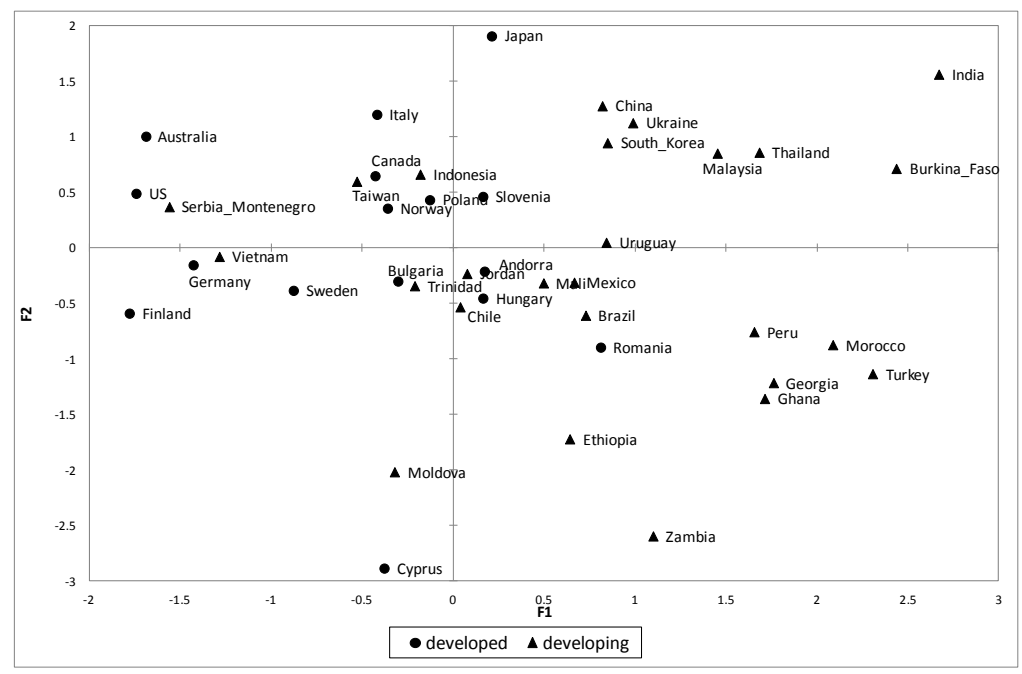

Fig. 9. Representation of the countries on the first factorial plane.

We note that most of the developed countries present high coefficients in trust in non-profit organizations. Developing countries present much more diverse patterns, related to their 
economic, environmental and cultural differences, which are more important for them than for the developed countries.

\section{The country-specific EASCA model: Application to China, India, USA,}

\section{Germany}

The EASCA model can be applied to a single country. As examples, we choose four major economies, present in our sample. Two are in the group of developing countries (China and India), and two are in the group of developed countries (the USA and Germany). These countries distinguish themselves by the negative performance of being among the largest producers of GHGs in their groups. Further motivation for choosing them is purely statistical. As shown in Fig. 8, the EASCA estimate for these four countries features an R2 higher than 0.1 , showing that the model has a relatively satisfactory fit for them.

Following the same steps as before, we first display the outer weights for each block of MVs in each country (Fig. 10). Additional numerical values and information about the statistical significance of the coefficients are shown in Error! Reference source not found. in the Appendix. In general, the outer weights of the MVs contributing to trust in technology are not significant. The only exceptions are tech1 for China and Germany and tech2 for India. Worthy of notice is the high coefficient of trust in NGOs (t_no_p2) in Germany and the negative coefficient of trust in government (t_no_p1) in the US. 

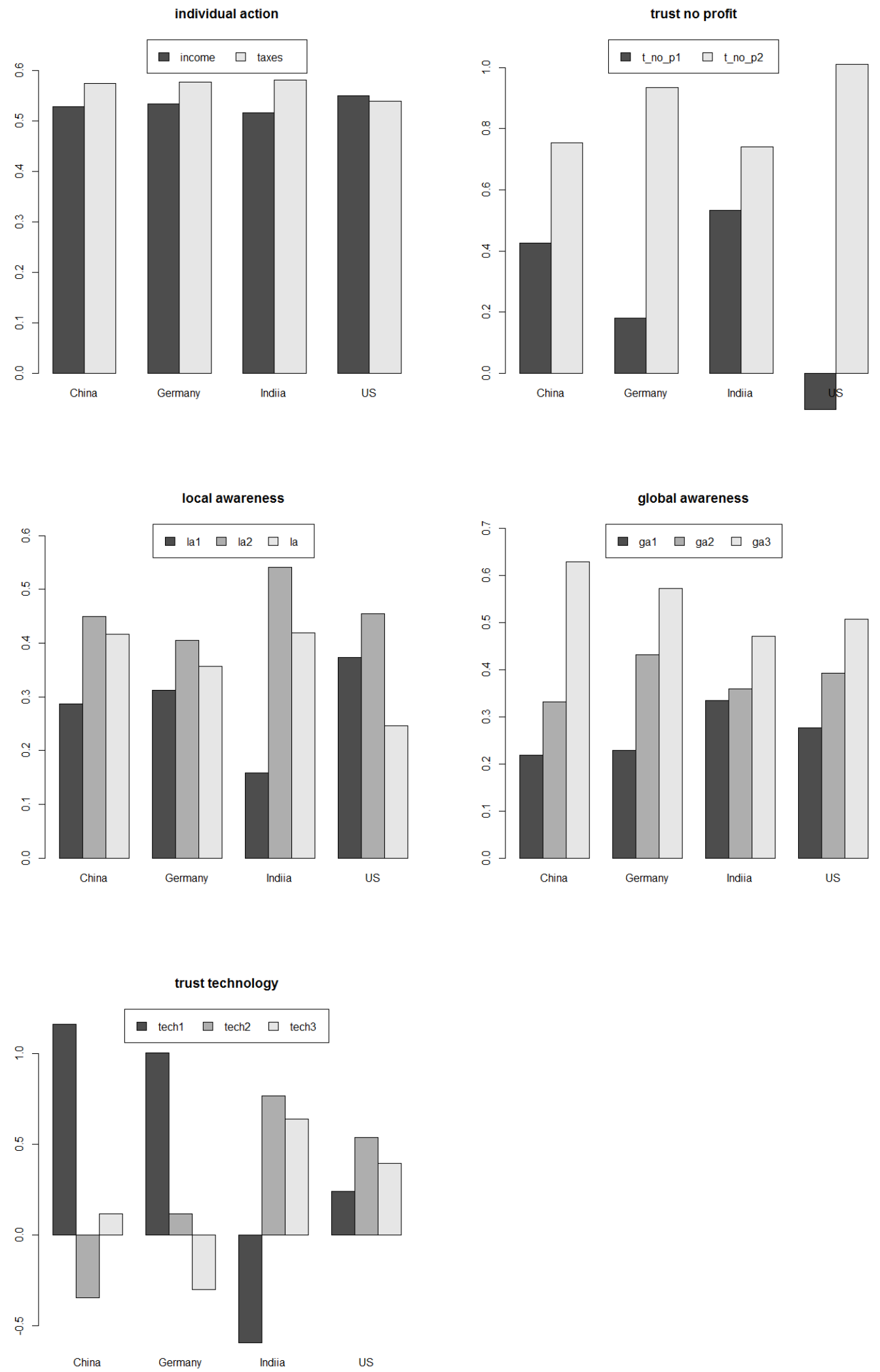

Fig. 10. Distribution of the outer weights for each LV in the four selected countries and considering the whole set of countries. 
Legend: $* * *$ significant at $1 \%, * *$ significant at $5 \%, *$ significant at $10 \%$

presents the paths coefficients between the key explanatory LVs and the individual environmental actions LV overall (first column) and the four selected countries.

Table 6. Path coefficients for individual actions using the whole set of countries and the four selected countries.

\begin{tabular}{lccccc}
\hline \multicolumn{1}{c}{ LV } & $\begin{array}{c}\text { Path- } \\
\text { coefficient }\end{array}$ & China & Germany & US & India \\
\hline awareness & $0.160^{* * *}$ & $0.080^{* *}$ & $0.161 * * *$ & $0.175^{* * *}$ & 0.055 \\
trust in people & $0.062^{* * *}$ & $0.075^{*}$ & $0.181 * * *$ & $0.082 * * *$ & $0.083^{* *}$ \\
trust in non-profit org. & $0.208^{* * *}$ & $0.219 * * *$ & $0.234 * * *$ & $0.388^{* * *}$ & $0.161^{* * *}$ \\
trust technology & $0.039 * * *$ & $0.136^{* * *}$ & $-0.086 * * *$ & $0.065^{* *}$ & $0.097 * *$ \\
trust in for-profit org. & $-0.030^{* * *}$ & 0.036 & $-0.097 * *$ & $-0.064 * *$ & $0.193 * * *$ \\
R2 & 0.074 & 0.098 & 0.141 & 0.227 & 0.127 \\
\hline
\end{tabular}

Legend: $* * *$ significant at $1 \%, * *$ significant at $5 \%, *$ significant at $10 \%$

At odds with the average tendency observed in the whole sample, trust in technology has a negative impact on individual action in Germany. This suggests that in this country that features the most developed manufacturing sector among the developed countries and is a world leader in manufacturing exports, the strong reliance on the capability of science and technological progress to address environmental risk is relaxing individual vigilance.

This responsibility shift is also observed in the negative coefficient related to trust in forprofit organizations. If companies can protect the environment, human action is less necessary. The same reaction is observed in the US, and both match the general pattern observed in developed countries. 
Both in the US and in Germany, environmental awareness is a key driver of individual action. By contrast, this coefficient is smaller (but significant) in China and not significant in India. It is highly probable that in the last ten years, this awareness de facto became a more important driver of individual action in these two developing countries.

The positive impact of trust in for-profit organizations and individual action as observed in India can be understood if individuals expect companies to contribute to the economic development of the country but without caring about the environment.

The comparison of results in Table 6 must be done carefully because statistically significant differences in the coefficients might not correspond to economically relevant differences. In this respect, we test the equality of path coefficients between countries (two by two) by means of a classical multi-group t test, where the standard error is estimated through bootstrap resampling (p-values for each comparison are shown in the Appendix, Table A2).

\section{Conclusion}

In the last decade, the public consensus in both developed and developing countries has moved in favor of recognizing the necessity for humankind to take strong and voluntary action in support of the environment, mainly by opposing the generation of GHGs. It is understood that in this field, progress can be achieved only at the international level.

Despite this consensus, international regulatory progress has been very slow and inconclusive. It is encouraging that in December 2015, the 188 governments that gathered in Paris for the COP21 agreed on voluntary targets of climate preservation that, if implemented, may prevent the Earth's temperature from rising by more than $2^{\circ} \mathrm{C}$. 
These hesitations and lack of more-energetic joint actions at the international level would suggest that in the fight for environmental protection, all levers should be activated.

This paper calls attention to the human attitude determinants of action. Our estimates of an original EASCA (Environment Action - Social Capital - Awareness) model with WVS data reveal the significant impact of social capital measures (trust in people, organizations and technology) on the willingness to act in favor of the environment, an impact that goes the beyond the natural awareness - action relationship.

At the time of the survey (2009), public awareness was high, on average, but it can, of course, further improve. The model reveals a strong positive relationship between local and global awareness and motivation to individually act in favor of the environment. This relationship appears to be stronger in the developed world than in the developing countries. Developing countries have to address simultaneously the challenge of economic growth and environmental protection, which might explain the weaker relationship. However, this would also suggest that in the developing countries, there is room for improving communication efforts in support of the environment.

In general, trust in technology is not "crowding out" the motivation for individual action in favor of the environment. Yet, more-accurate country-based estimates of the EASCA model can reveal that in some countries, such a responsibility shift can be observed (in Germany, for instance). Thus, it is important for governments to understand the subtle mechanisms through which beliefs impact individual action in their country and to try to adapt their environmental communication and action accordingly. 
In general, trust in for-profit organizations (companies) has a negative impact on individual action, as if respondents are victims of a responsibility shift. This negative impact is not significant in the developing world, yet it is strong and significant in the developed countries. This finding raises a responsibility-square problem, or the responsibility of companies in implementing their CSR strategies. Communicating in too extensively on the good actions taken by firms in favor of the environment might entail the negative unintended effect of reducing individual support toward environmentally friendly taxes and policies. Thus, a truly responsible environmental protection action should entail only the right amount of communication, and some modesty would be welcome.

Over time, the environment has become a matter of utmost concern for the public and policymakers. Since survey questions are not incentive-compatible (Bertrand and Mullainathan, 2001; Dohmen et al., 2011), economists generally dislike talking about opinions and attitudes, preferring to focus on the cold numbers and objective relationships. Without challenging this approach, our analysis suggest that beliefs, emotions and attitudes can play an important role in shaping individual action in favor of environmentally friendly policies and for that reason should be taken into account in the design of responsible policies.

\section{Discolosure statement}

The authors declare that they have no relevant or material financial interests that relate to the research described in the paper. 


\section{References}

Aghion, P., Algan, Y., Cahuc, P., Shleifer, A., 2010. Regulation and distrust. Q. J. Econ. 125, 1015-1049.

Algan, Y., Cahuc, P., 2010. Inherited trust and growth. Am. Econ. Rev. 100, 2060-2092.

Arrow, K.J., 1974. The Limits of Organization. Norton, New York.

Bamberg, S., Möser, G., 2007. Twenty years after Hines, Hungerford, and Tomera: a new meta-analysis of psycho-social determinants of pro-environmental behaviour. J. Environ. Psychol. 27, 14-25.

Bertrand, M., Mullainathan, S., 2001. Do people mean what they say? Implications for subjective survey data. Am. Econ. Rev. 91, 67-72.

Borden, R.J., 1984. Psychology and ecology: beliefs in technology and the diffusion of ecological responsibility. J. Environ. Educ. 16, 14-19.

Botzen, W.J.W., Gowdy, J.M., van den Bergh, J.C.J.M., 2008. Cumulative CO2 emissions: shifting international responsibilities for climate debt. Clim. Policy 8, 569-576.

Carattini, S., Jo, A., 2016. Trust and CO2 emissions: cooperation on a global scale. https://pdfs.semanticscholar.org/0541/b6201ac6ce5ae859b7487ab86ce1472e8813.pdf.

Carroll, A.B., 1999. Corporate social responsibility: evolution of a definitional construct. Bus. Soc. $38,268-295$.

Dasgupta, P., 2000. Trust as a commodity, in: Gambetta, D. (Ed.), Trust: Making and Breaking Cooperative Relations. Oxford University Press, Oxford, pp. 49-72.

Dohmen, T., Falk, A., Huffman, D., Sunde, U., Schupp, J., Wagner, G.G., 2011. Individual risk attitudes: measurement, determinants, and behavioral consequences. J. Eur. Econ. Assoc. 9, 522-550.

Drews, S., van den Bergh, J.C.J.M., 2016. What explains public support for climate policies? A review of empirical and experimental studies. Clim. Policy 16, 855-876. 
Economist, 2015a. Raise the green lanterns. Economist, December 5, 50.

Economist, 2015b. Special report climate change. Economist, November 28, 3-16.

Esposito-Vinzi, V., Chin, W.W., Henseler, J., Wang, H. (Eds.), 2010. Handbook of Partial Least Squares. Springer, Berlin.

Gambetta, D., 2000. Can we trust?, in: Gambetta, D. (Ed.), Trust: Making and Breaking Cooperative Relations. Oxford University Press, Oxford, pp. 213-237.

Hines, J.M., Hungerford, H.R., Tomera, A.N., 1987. Analysis and synthesis of research on responsible environmental behavior: a meta-analysis. J. Environ. Educ. 18, 1-8.

Hsu, A., Xu, K., Weinfurter, A., Rauber, R., Gupta, A., Jain, U., Yick, C., Thomas, R., 2016. Taking stock of global climate action. Yale University, Yale DATA-Driven Environmental Solutions Group, New Haven.

Inglehart, R., 1995a. Changing values, economic development and political change. Int. Soc. Sci. J. 47, 379-403.

Inglehart, R., 1995b. Public support for environmental protection: objective problems and subjective values in 43 societies. Political Sci. Politics 28, 57-72. doi:10.2307/420583.

IPCC, 2014. Climate Change 2014: Synthesis Report. Contribution of Working Groups I, II and III to the Fifth Assessment Report of the Intergovernmental Panel on Climate Change. Intergovernmental Panel on Climate Change, Geneva. http://www.ipcc.ch/report/ar5/syr/, accessed on Dec.15.2016.

Kaiser, F.G., Wölfing, S., Fuhrer, U., 1999. Environmental attitude and ecological behaviour. J. Environ. Psychol. 19, 1-19.

Kerschner, C., Ehlers, M.-H., 2016. A framework of attitudes towards technology in theory and practice. Ecol. Econ. 126, 139-151. 
Krugman, P., 2010. Building a green economy. New York Times. http://www.nytimes.com/2010/04/11/magazine/11Economy-t.html?_r=0 (accessed 07.04.10).

Matten, D., Moon, J., 2008. "Implicit" and "explicit" CSR: a conceptual framework for a comparative understanding of corporate social responsibility. Acad. Manage. Rev. 33, 404-424.

Mauro, P., 1995. Corruption and growth. Q. J. Econ. 110, 681-712.

McKean, R.N., 1975. Economics of trust, altruism and corporate responsibility, in: Phelps, E.S. (Ed.), Altruism, Morality and Economic Theory. Russel Sage Foundation, New York, pp. 29-44.

Najam, A., Huq, S., Sokona, Y., 2003. Climate negotiations beyond Kyoto: developing countries concerns and interests. Clim. Policy 3, 221-231.

Noreen, E., 1988. The economics of ethics: a new perspective on agency theory. Acc. Organ. Soc. $13,359-369$.

North, D.C., 1990. Institutions, Institutional Change and Economic Performance. Cambridge University Press, Cambridge, UK.

Putnam, R.D., 2001. Bowling Alone: The Collapse and Revival of American Community. Simon and Schuster, New York.

Skea, J., Lechtenböhmer, S., Asuka, J., 2013. Climate policies after Fukushima: three views. Clim. Policy 13, 36-54.

Tirole, J., 2016. Economie du bien commun. PUF, Paris.

Tjernström, E., Tietenberg, T., 2008. Do differences in attitudes explain differences in national climate change policies? Ecol. Econ. 65, 315-324.

Torgler, B., Garcia-Valinas, M.A., 2007. The determinants of individuals' attitudes towards preventing environmental damage. Ecol. Econ. 63, 536-552. 
UNFCCC Secretariat, 2015. Report of the Conference of the Parties on Its Twenty-First Session, Held in Paris From 30 November to 13 December 2015. Addendum. Part Two: Action Taken by the Conference of the Parties at Its Twenty-First Session. United Nations Framework Convention on Climate Change, Geneva. http://unfccc.int/documentation/documents/advanced_search/items/6911.php?priref=6 00008865

von Weizsäcker, E., Hargroves, K., Smith, M., Desha, C., Stasinopoulos, P., 2009. Factor 5: Transforming the Global Economy through $80 \%$ Increase in Resource Productivity. Earthscan, London.

Winston, A., 2010. The most powerful green NGO you've never heard of. Harv. Bus. Rev., October 5.

Wold, H., 1985. Partial least squares, in: Kotz, S., Johnson, N.L. (Eds.), Encyclopedia of Statistical Sciences. Wiley, New York.

WVS, 2008. World Values Survey Wave 5 2005-2008 official aggregate, v.20140429. World Values Survey Association, Vienna. www.worldvaluessurvey.org.

Ziegler, A., 2015. On the relevance of ideology and environmental values for climate change beliefs, climate policy support, and climate protection activities: an empirical cross country analysis. Beiträge zur Jahrestagung des Vereins Für Socialpolitik 2015: Ökonomische Entwicklung - Theorie und Politik - Session: Environmental Economics V, No. E13-V3. 


\section{ONLINE APPENDIX (NOT FOR PUBLICATION)}

Table A1. Classification of the countries in the WVS as developed or developing, according to the UN IPCC Classification 2015.

\begin{tabular}{ll}
\hline Developing & Developed \\
\hline Brazil & Andorra \\
Burkina_Faso & Australia \\
Chile & Bulgaria \\
China & Canada \\
Ethiopia & Cyprus \\
Georgia & Finland \\
Ghana & Germany \\
India & Hungary \\
Indonesia & Italy \\
Jordan & Japan \\
Malaysia & Norway \\
Mali & Poland \\
Mexico & Romania \\
Moldova & Slovenia \\
Morocco & Sweden \\
Peru & US \\
Serbia_Montenegro \\
South_Korea & \\
Taiwan & \\
Thailand & \\
Trinidad & \\
Turkey & \\
Ukraine & \\
Uruguay & \\
Vietnam & \\
Zambia & \\
\hline
\end{tabular}


Table A2. p-values of the test on the equality of path coefficients between pairs of countries.

Path coefficient (local awareness -> awareness):

\begin{tabular}{|l|l|l|l|l|}
\hline & China & Germany & India & US \\
\hline China & & & & \\
\hline Germany & 0.002 & & & \\
\hline India & 0.219 & 0.000 & & \\
\hline US & 0.361 & 0.000 & 0.462 & \\
\hline
\end{tabular}

Path coefficient (global awareness -> awareness):

\begin{tabular}{|l|l|l|l|l|}
\hline & China & Germany & India & US \\
\hline China & & & & \\
\hline Germany & 0.000 & & & \\
\hline India & 0.959 & 0.000 & & \\
\hline US & 0.385 & 0.000 & 0.272 & \\
\hline
\end{tabular}

Path coefficient (awareness -> individual action):

\begin{tabular}{|l|l|l|l|l|}
\hline & China & Germany & India & US \\
\hline China & & & & \\
\hline Germany & 0.140 & & & \\
\hline India & 0.691 & 0.066 & & \\
\hline US & 0.046 & 0.782 & 0.014 & \\
\hline
\end{tabular}

Path coefficient (trust people -> individual action):

\begin{tabular}{|l|l|l|l|l|}
\hline & China & Germany & India & US \\
\hline China & & & & \\
\hline Germany & 0.060 & & & \\
\hline India & 0.840 & 0.075 & & \\
\hline US & 0.889 & 0.026 & 0.918 & \\
\hline
\end{tabular}

Path coefficient (trust in non-profit -> individual action):

\begin{tabular}{|l|l|l|l|l|}
\hline & China & Germany & India & US \\
\hline China & & & & \\
\hline Germany & 0.820 & & & \\
\hline India & 0.314 & 0.202 & & \\
\hline US & 0.001 & 0.001 & 0.000 & \\
\hline
\end{tabular}

Path coefficient (trust in profit -> individual action):

\begin{tabular}{|l|l|l|l|l|}
\hline & China & Germany & India & US \\
\hline China & & & & \\
\hline Germany & 0.025 & & & \\
\hline India & 0.016 & 0.000 & & \\
\hline US & 0.044 & 0.435 & 0.000 & \\
\hline
\end{tabular}

Path coefficient (trust in technology -> individual action):

\begin{tabular}{|l|l|l|l|l|}
\hline & China & Germany & India & US \\
\hline China & & & & \\
\hline Germany & 0.000 & & & \\
\hline India & 0.597 & 0.034 & & \\
\hline US & 0.153 & 0.012 & 0.622 & \\
\hline
\end{tabular}




\begin{tabular}{|c|c|c|c|c|}
\hline $\begin{array}{l}\text { ESSEC Business School } \\
3 \text { avenue Bernard-Hirsch } \\
\text { CS } 50105 \text { Cergy } \\
95021 \text { Cergy-Pontoise Cedex } \\
\text { France } \\
\text { Tel. + } 33 \text { (0) } 134433000 \\
\text { www.essec.edu }\end{array}$ & $\begin{array}{l}\text { ESSEC Executive Education } \\
\text { CNIT BP } 230 \\
92053 \text { Paris-La Défense } \\
\text { France } \\
\text { Tel. }+33 \text { (0) } 146924900 \\
\text { www.executive-education.essec.edu }\end{array}$ & $\begin{array}{l}\text { ESSEC Asia-Pacific } \\
5 \text { Nepal Park } \\
\text { Singapore } 139408 \\
\text { Tel. +65 } 68849780 \\
\text { www.essec.edu/asia }\end{array}$ & $\begin{array}{l}\text { ESSEC Africa-Atlantic } \\
\text { Plage des Nations } \\
\text { Sidi Bouknadel } \\
\text { Rabat-Salé } \\
\text { Morocco } \\
\text { Tel. +212 (0)5 } 30104019 \\
\text { www.essec.edu }\end{array}$ & $\begin{array}{l}\text { ESSEC Africa-Indian Ocean } \\
\text { Royal Road, Pierrefonds } \\
\text { Mauritius } \\
\text { Tel. + } 2304012400 \\
\text { www.essec.edu } \\
\text { www.icsia.mu }\end{array}$ \\
\hline
\end{tabular}

\section{- MOROCCO}

\section{Contacts}

Centre de Recherche

+33 (0)134433091

research.center@essec.fr

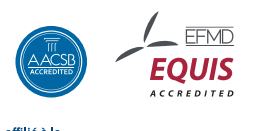

Cí CCI PARIS ILE-DE-FRANCE

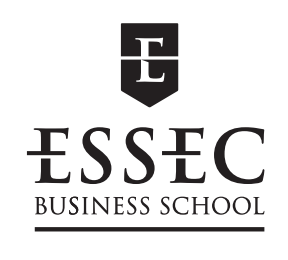

